that while the native visits the white man on a friendly basis and brings certain of his troubles to him, this does not apply to witchcraft, because the white man does not believe in it. The problem is to teach the black man to think 'white', just as we ourselves in many parts of Africa are trying to think 'black'. Hence Mr. Melland stressed the value as an educative influence of carefully selected films of British life which should be brought before the native. While it is perfectly obvious that as the conditions of life and hygiene in tropical Africa become better understood, the number of white settlers will increase, it is frequently overlooked that the black man is equally a permanent element in the future situation which must be taken into account. As Mr. Melland pointed out, he will not disappear as the red man in America or the Australian blackfellow have disappeared, nor will he survive as an historical curiosity. The Bantu are the most virile and persistent racial stock extant, and they outnumber the white man in the highlands of Africa by fourteen to one. Lord Buxton, judging from his own experience, thinks that the belief in witcheraft is by no means so strong as it was some years ago; but taking this as symptomatic of advance in other directions, progress must be slow. If it were not for difficulties of which there has been abundant evidence recently, it would seem scarcely necessary to urge the necessity for the scientific study of native ways of thought and institutions to ensure that progress in native development is in a direction which will permit of the two races living side by side in one community, as forecast by Mr. Melland.

\section{Aims of Anthropological Research}

Prof. Franz Boas of Columbia University, in his presidential address to the American Association for the Advancement of Science at the meeting at Atlantic City in December last, made a survey of present-day methods of approach in anthropological research, which was remarkable not only for the thoroughness with which it traversed the ground, but also for the critical acumen which probed weak spots in the theories dominant at the moment in the various schools of thought. He suggested caution in estimating the possibilities of formulating general laws. His final conclusion is that the study of 'foreign cultures' should enable us to see how many of our lines of behaviour, that we believe to be founded deep in human nature, are actually expressions of our culture and subject to modification with changing culture. "By a study of the universality and variety of cultures," he said, "anthropology may help us to shape the future course of mankind." Prof. Boas, holding that the objective of anthropology is the attempt to understand the steps by which man has come to be what he is biologically, psychologically and culturally, also holds that its material must be historical in the widest sense of the term, and that in the argument for diffusion it is not a safe method to assume that all analogous cultural phenomena must be related. "It is necessary," he says, "to demand in every case proof of the historical relation, which should be the more rigid the less evidence there is of actual recent or early contact." Prof. Boas's address appears in full in Science for December 30, pp. 605-613.

\section{Dr. John Roebuck, F.R.S., I7I8-94}

WE learn with interest that the tomb of Dr. J. Roebuck, one of the founders of the famous Carron Iron Works, Falkirk, has recently been restored. Roebuck was born in Sheffield in 1718 and after studying in Edinburgh took the degree of M.D. at Leyden. Returning home, he practised in Birmingham, but, becoming interested in practical chemistry, he was successful in introducing the use of lead chambers into the manufacture of sulphuric acid. In 1759, with Samuel Garbett and William Cadell, he founded the Carron Company, the first concern in Scotland to use coal for smelting iron and the first to use ironstone from the carboniferous formation of central Scotland. Roebuck was the friend of Watt, Boulton, Smeaton and Black, and was a fellow of the Royal Societies of London and Edinburgh. He died in July 1794 at Bo'ness, near Grangemouth, and was buried in Carriden churchyard. His grave is surrounded by a low wall while at the head of it is a marble tablet bearing a long inscription in Greek and Latin, referring to his studies in chemistry and metallurgy, which sciences "he expounded and adapted to human needs with a wonderful fertility of genius and a high degree of painstaking labour". The restoration of the tomb has been carried out by the descendants of Dr. Roebuck and the Carron Company. The Company, it may be added, has published an interesting series of leaflets recalling some of the famous men who have been associated with the works.

\section{Lancaster Frankland Society}

Aт a meeting held in the Storey Institute, Lancaster, on January 18-the anniversary of the birth of Sir Edward Frankland in 1825-a proposal was brought forward to form a society in Lancaster to perpetuate the memory of this great chemist. Prof. H. E. Armstrong, Frankland's oldest living pupil, in the course of an interesting address, reported in the Lancaster Observer of January 20, lent his support to the proposal. Frankland, he said, went to Lancaster at a very early age and remained until 1845, attending first a private school and afterwards the Royal Grammar School; a valuable part of his training was obtained also during his apprenticeship in a local druggist's shop, for there he learnt to use his hands. Prof. Armstrong expressed the hope that the founders of the organisation would remember Frankland not only as a chemist but also as a man of wide attainments, and that besides chemists they would include botanists, geologists, and particularly sanitarians-for Frankland's important work in giving Great Britain a pure water supply lay in association with sanitary science. In supporting the proposal, Dr. Shackleton Bailey mentioned various past pupils of the Royal Grammar School, Lancaster, who have achieved eminence in science, among them 
being Sir Edward Frankland in chemistry, Sir Richard Owen in biology, Prof. Seward in botany, and Prof. Marr in geology. A letter of support was read from Prof. P. F. Frankland. Prof. Armstrong is to be president of the new society, which, it has been decided, shall be called the Lancaster Frankland Chemical Society.

\section{Biology's Message for Civilisation}

IN an address to Sections D and F of the South African Association for the Advancement of Science in July 1932, Prof. H. B. Fantham, recently elected to the chair of zoology in McGill University, Montreal, essayed to interpret biology's message for the plight of modern civilisation (South African J. Sci., vol. 29, p. 533). Prof. Fantham regards the expenditure on education as excessive, and the subjects taught too many ; his own ideal list includes general elementary science (including biology), the languages of the country, reading; writing, arithmetic, economic and human geography, history, some cultural subject like singing, needlework and cookery for girls, drawing and woodwork for boys, moral principles, and perhaps simple drill, anything beyond these to be paid for by the parents concerned. Elementary education alone should be free, for so-called free education is 'free' only to the parents directly concerned and not to the community. The mechanisation of the modern world is a disharmony, which is narrowing and starving human life. Doles are "perhaps the greatest biological mistake in the social organisation of the present age" ; relief should be made conditional on the giving of service. Generally, Prof. Fantham holds that there is too much administration, too much organisation, too many conferences and too much mechanisation, so that man's environment has become too artificial, and the result of the disharmony is expressed in instability and unrest. Some suggestions made by the author are that government must be by paid business managers trained in science and administration; that production must be adjusted to demand and the scientific organisation of distribution; that wages should be judged by their purchasing power; that the movement back to the land should be encouraged; that wars should cease and war debts be cancelled; and that eugenic measures should be employed to cope with problems of over-population.

\section{The Language Difficulty and Scientific Progress}

DURING the course of a year we receive many journals, reports of congresses, and papers printed in languages which, it must be admitted, are unfamiliar to the majority of scientific workers and sometimes in alphabets which add to the difficulties of interpretation. Fortunately, the custom is growing of adding to each paper a summary of its contents in English, French or German, but no summary can ever replace, for a scientific worker, the detail of the method and observations of the paper sum. marised. The relegating to comparative obscurity, on account of the language difficulty, of many papers of value is all against the progress of scientific know. ledge, and it is for that reason that we venture to appeal again for an increased use, if not in whole at least in summary, of the languages which have come to be recognised as the general vehicle of scientific researches. The tendency of recent times was the subject of discussion at the fifteenth annual meeting of the American Society of Ichthyologists and Herpetologists in Washington, D.C., in May 1932, and the following resolution was passed unanimously : "Whereas, a large number of ichthyologists and herpetologists of countries using non-Latin alphabets are publishing their papers in the English language; therefore, be it resolved that the American ichthyologists and herpetologists, through their Society, desire to thank their fellow scientists of other lands for publishing in English."

\section{Use of the English Language}

AT the Friday evening discourse at the Royal Institution on February 3, Dr. Cyril Norwood discussed the use of the English language. Dr. Norwood directed attention to the particular dangers to present-day writers arising from the rapid wear and tear of words and phrases, and the decay of metaphors, and pointed out that these arise from, among other things, the excessive use of technical language which reduces words to a system of symbols. Illustrations from the works of leader writers and of men of science were given to show the kinds of error which are very frequent, and to illustrate methods of style which delay the reader's appre. hension and defeat the writer's object. The methods of Darwin, who was without natural gifts of style, but took infinite pains to render his writing clear and attractive, were examined and Dr. Norwood suggested that Darwin's example could well be followed. A similar study of Huxley was made, and Dr. Norwood quoted a passage from his writings which he considers is a model of written English.

\section{Economic Value of Agricultural Science}

There must be few engaged in research who have not been called upon to justify the policy of scientific examination of technical problems in face of the apathy or distrust of the practical man. This is particularly so in the case of agriculture, in which it is still possible to continue by the use of traditional methods. Fortunately, the list of scientific achievements which have given the cultivator vastly greater command over the forces of Nature is a long one; and the critic may be made to realise that practically the whole agricultural technique that was not possessed by his grandfather is the direct outcome of scientific research. In an address delivered to the Wellington Philosophical Society on October 26, Lord Bledisloe, Governor General of New Zealand, very ably sets out the economic value of agricultural science. Addressing his remarks to the primary producer, Lord Bledisloe points out that only by fostering scientific research and applying its results to practice can a place be maintained in world markets, continually more congested and more exacting 